\title{
Inhibition of heparanase protects against pancreatic $\beta$-cell death in streptozotocin-induced diabetic mice via reducing inflammatory cell infiltration
}

\author{
Wen-Yu Song ${ }^{1}$, Xiao-Han Jiang ${ }^{1}$, Kai Li ${ }^{1}$, Yan Wang ${ }^{1}$, Yun Xia ${ }^{1}$, Ming-Xuan Zhou ${ }^{1}$, \\ Chen-Yu Zhang ${ }^{1}$, Chong-Chong Yin ${ }^{1}$, Chen Qiu ${ }^{1}$, Ying Ding ${ }^{1}$, Peng Sun ${ }^{1}$, and Xiao Han ${ }^{1}$ \\ ${ }^{1}$ Nanjing Medical University
}

May 5, 2020

\begin{abstract}
Background and Purpose Intra-islet heparan sulfate (HS) plays an important role in the maintenance of the pancreatic islet function. The aim of this study was to investigate the effect mechanism of HS loss on the functioning of islets in diabetic mice. Experimental Approach The hypoglycemic effect of a heparanase inhibitor, OGT2115, was tested in streptozotocin-induced diabetic mice. The islets of pancreas sections were also stained to reveal their morphology. An insulinoma MIN6 cell line and primary isolated murine islets were used to investigate the effect of OGT2115 in vitro. Key Results Intra-islet HS was clearly lost in streptozotocin-induced diabetic mice due to the increased heparanase expression in damaged islets. OGT2115 prevented intra-islet HS loss to improve the glucose profile and insulin secretion in streptozotocin-treated mice. The apoptosis of pancreatic beta cells, the infiltration of mononuclear macrophages, CD4 and CD8 positive T-cells in islets was reduced by OGT2115 in streptozotocin-treated mice, but OGT2115 did not alter the direct streptozotocin-induced damage in vitro. The expression of heparanase was increased in high glucose-treated isolated islets but not in response to direct streptozotocin stimulation. Further experiments showed that high glucose stimuli could decrease the expression of peroxisome proliferator-activated receptor gamma $(\mathrm{PPAR} \gamma)$ in cultured islets, thereby relieving the PPAR $\gamma$-induced inhibition of heparanase gene expression. Conclusion and Implications Hyperglycemia could cause intra-islet HS loss by elevating the expression of heparanase, thereby aggravating inflammatory cell infiltration and islet damage. Inhibition of heparanase might provide benefit for pancreatic beta cell protection in type 1 diabetes.
\end{abstract}

\section{Abbreviations}

Heparan sulfate (HS)

Heparanase (Hpse)

Heparan sulfate proteoglycan (HSPG)

Peroxisome proliferator-activated receptor gamma (PPAR $\gamma$ )

Streptozotocin (STZ)

Non-obese diabetic (NOD)

Intraperitoneal Glucose tolerance test (IPGTT)

Glucose-stimulated insulin secretion (GSIS)

Mononuclear Cells (MNCs) 
Glomerular Basement Membrane (GBM)

Peroxisome Proliferator Responsive Elements (PPRE)

Pancreatic and Duodenal homeobox factor 1 (PDX1)

\section{Introduction}

Type 1 diabetes is characterized by direct and specific pancreatic beta cell destruction that causes an absolute deficiency of insulin secretion and hyperglycemia (Noble, 2015). The autoimmune inflammatory response of beta cells is widely considered to underlie the mechanism of beta cell dysfunction in type 1 diabetes. Following inflammatory injury of prophase beta cells, an accumulation of mononuclear cells (MNCs) and lymphocytes occurs around the pancreatic islets, and these MNCs produce cytokines, such as interleukin- $1 \beta$ (IL-1 $\beta$ ), tumor necrosis factor (TNF- $\alpha$ ), and interferon (IFN- $\gamma$ ), that trigger beta cell apoptosis (Mallone et al. , 2011). Once the beta cell destruction has occurred, specific $\mathrm{T}$ cells, like $\mathrm{CD} 4^{+} \mathrm{T}$ cells and $\mathrm{CD} 8^{+} \mathrm{T}$ cells, are activated and further damage beta cells (Ferris et al. , 2014) Overall, the immune inflammatory reaction is a key element in the process of the beta cell dysfunction in type 1 diabetes.

Heparan sulfate (HS) is a linear polysaccharide expressed broadly on cell surfaces and in the cell matrix. HS is attached to a core protein to form heparan sulfate proteoglycan (HSPG), and highly associated with various biological processes, such as angiogenesis, invasion, and metastasis of tumors (Iozzo, 1998). A role for HS in diabetes has been indicated in recent years. The lack of HS in the human glomerular basement membrane affects the permeability of endothelial cells in diabetic nephropathy (Edge et al. , 2000).And in gestational diabetes mellitus, the reduction of HS expression in the placenta affects early embryonic development (Ginath et al. , 2015). In type 1 diabetes, HS that localized in the peri-islet basement membrane may act as a physical barrier that protects beta cells from attack by immune inflammatory reactions (Irving-Rodgers et al. , 2008). Loss of intra-islet HS is directly related to the apoptosis of beta cells in non-obese diabetic (NOD) mice characterized by autoimmune beta cell damage (Ziolkowski et al. , 2012). Further studies confirmed that a decrease of HS in the islets aggravates the oxidative stress damage by free radicals (Simeonovic et al. , 2018). Thus, further exploration of the possible involvement of intra-islet HS in the maintenance of the function and survival of the islets, together with an in-depth understanding of the underlying mechanism, could improve knowledge regarding the development of islet dysfunction during type 1 diabetes.

The aim of the present study was to investigate the role of intra-islet HS in a type 1 diabetes mouse model. This model is established by multiple injections of low doses of streptozotocin (STZ) to C57BL/6 mice; these injections damage a few islet beta cells and induce further immune injury (Lin et al. , 2010). Intra-islet HS level and the expression of heparanase, the key enzyme that hydrolyzes HS (Whiteheadet al. , 2018), in the islets were investigated in STZ mice. The effect of a small molecule inhibitor of heparanase, OGT2115, on the glucose profile, insulin secretion, morphological alteration of the islets in the STZ mice was investigated. Further experiments studied the effect of OGT2115 in vitro and the regulation of heparanase expression in pancreatic beta cells.

\section{Methods and Materials}

\section{Animal experiments}

All animal use was approved by the Animal Care and Ethical Committee of Nanjing Medical University. C57BL/6J mice [RRID: IMSR_JAX:000664] (male, 8-week old, $22 \pm 2 \mathrm{~g}$ ) were obtained from Animal Resource Center (Nanjing Medical University, Nanjing, China). Mice were housed under a $12 \mathrm{~h}$ light, $12 \mathrm{~h}$ dark cycle, with food and water freely accessible. After a 4-hour fast, STZ (Sigma-Aldrich, St. Louis, MO, USA) diluted in Na-citrate buffer $(\mathrm{PH}=4.5)$ was injected intraperitoneally at a dose of $50 \mathrm{mg} / \mathrm{kg}$ for consecutive 5 days to destroy the islet beta cells of the mice. Hyperglycemia was defined as 2 consecutive random blood glucose readings of $16.7 \mathrm{mmol} / \mathrm{L}$ or higher.

For heparanase inhibition, OGT2115 (Tocris, Minneapolis, MN, USA) was dissolved in dimethyl sulfoxide 
(DMSO) and diluted to different concentrations with sterile water containing $5 \%$ Tween 80 and 30\% PEG400. STZ mice received vehicle (sterile water containing 1\% DMSO, 5\% Tween 80, and 30\% PEG400), a low OGT2115 dosage $(3 \mathrm{mg} / \mathrm{kg})$ or a higher dosage $(10 \mathrm{mg} / \mathrm{kg})$. OGT2115 and vehicle were subcutaneous injected daily for 4 weeks. The food intake, body weight gain and random blood glucose levels of the mice were followed up every week. All animal experiments were performed and analyzed through blinded experimenters. Each mouse in STZ or control group was numbered randomly within the weight range. After being divided randomly in each group, the animals were given their permanent number in the cages.

\section{Intraperitoneal Glucose tolerance test (IPGTT) and insulin measurement}

After the 4-week drug administration period, the animals were fasted for 12 hours and glucose $(2 \mathrm{~g} / \mathrm{kg}$ of body weight dissolved in saline) was intraperitoneally injected. Blood glucose was then measured from tail vein blood with a glucometer (Roche Diagnostics, Indianapolis, IN, USA) and test strips at 0, 30, 60, 90, and 120 min following the glucose injection. The results were displayed as a blood glucose curve and the area under the curve (AUC). Before and $30 \mathrm{~min}$ after glucose loading, additional blood samples were collected and serum insulin concentrations were measured using insulin ELISA kits (EZassay, Shenzhen, China).

\section{Morphological staining}

After the OGT2115 administration, the mice were euthanized with $\mathrm{CO}_{2}$. The pancreas was removed and fixed in $4 \%$ neutral-buffered formalin and processed for paraffin embedding (Sunet al. , 2018). Sections were stained with Alcian blue (Sigma, $0.2 \%$ in $0.2 \mathrm{~mol} / \mathrm{L}$ phosphate buffer, $0.65 \mathrm{~mol} / \mathrm{L} \mathrm{MgCl} 2$, pH 5.8) and counterstained with safranin O (Solarbio, Beijing, China). For immunostaining, the sections were immersed in citrate buffer $(0.01 \mathrm{M}, \mathrm{pH}=6.0)$ at $95 \mathrm{degC}$ for $5 \mathrm{~min}$ to perform heat-induced antigen retrieval. The primary antibodies used were listed in Table S1. Especially, before using 3G10 antibody [US Biological Cat\#H189075, RRID: AB_2722745], $1 \mathrm{mU}$ heparitinase I (Amsbio, Madrid, Spain) was incubated to exposure $3 \mathrm{G} 10$ epitope of HS. For immunohistochemistry, DAB kits (Gene Tech, Shanghai, China) were used to show the immunohistochemical staining and the nuclei were stained with hematoxylin. Images were obtained with a DP70 camera (Olympus, Tokyo, Japan). Image J software [RRID: SCR_003070] (V1.8.0, NIH, Bethesda, $\mathrm{MD}$, USA) was used to calculate the intensity of the immunohistochemical staining, expressed based on islet area.

For immunofluorescence, the secondary antibodies were: donkey anti-mouse/rabbit/Guinea Pig IgG conjugated with AlexaFluor 488/594 (Invitrogen, Carlsbad, CA, USA). The nuclei were stained with DAPI (Sigma). Apoptotic cells were stained using a TdT-mediated dUTP Nick-End Labeling (TUNEL) kit (Vazyme Biotech, Nanjing, China) following the manufacturer's protocol. The fluorescence images were scanned using a confocal microscope (Olympus F1000).

\section{Cell culture and treatment}

Cell culture reagents were all purchased from Gibco (Oakland, CA, USA). MIN6 cells [BCRJ Cat\#0293, RRID: CVCL_0431] were cultured in Dulbecco's modified Eagle's medium (DMEM) with 25.5 mM glucose and $10 \%$ fetal bovine serum (FBS) and antibiotics in a $37 \mathrm{degC}$ incubator with $5 \% \mathrm{CO}_{2}$. STZ (10 mM) was added to the culture medium of MIN6 cells in the presence of different doses of OGT2115. For luciferase reporter gene assays, $293 \mathrm{~T}$ cells were cultured in high glucose DMEM with $10 \% \mathrm{FBS}$ at $37 \mathrm{degC}$ in $5 \% \mathrm{CO}_{2}$. For cell viability assays, MIN6 cells in 96-well plates were divided into different treatment groups (five replicated wells). After treatment, 3-(4,5-Dimethylthiazol-2-yl)-2,5-diphenyltetrazolium bromide (MTT, Sigma) was used to measure cell viability, as previously described (Sunet al. , 2016).

\section{Isolation and culture of murine islets}

The isolation of murine islets was described in our previous study (Hanet al. , 2001). Briefly, the pancreas was digested with collagenase (Sigma, $1 \mathrm{mg} / \mathrm{mL}$ ) via common bile duct injection. The digest was then washed and fractionated by gradient centrifugation in Histopaque (Sigma). The islets were viewed with a stereomicroscope and picked up with a pipette. Isolated islets were cultured in RPMI 1640 with $10 \%$ FBS in an incubator of $5 \% \mathrm{CO}_{2}$ at $37 \mathrm{deg} \mathrm{C}$ overnight. 


\section{Glucose-stimulated insulin secretion (GSIS)}

The islets were seeded and pretreated in high glucose/STZ with/without OGT2115 for $24 \mathrm{~h}$. The islets were then rinsed and incubated for $1 \mathrm{~h}$ at $37 \mathrm{degC}$ in Krebs-Ringer bicarbonate $\left(115 \mathrm{mM} \mathrm{NaCl}, 24 \mathrm{mM} \mathrm{NaHCO}{ }_{3}\right.$, $5 \mathrm{mM} \mathrm{KCl}, 2.5 \mathrm{mM} \mathrm{CaCl}_{2}, 1 \mathrm{mM} \mathrm{MgCl}_{2}, 10 \mathrm{mM}$ HEPES, and $0.2 \%$ bovine serum albumin, $\mathrm{pH}=7.2$ ) containing $5 \mathrm{mM}$ or $25 \mathrm{mM}$ glucose. After incubation, the supernatant was collected and the concentration of insulin was measured with a radioimmunoassay (RIA) kit (Beijing North Institute of Biological Technology, Beijing, China).

\section{Isolation of total RNA and qPCR assays}

Cells or murine islets were homogenized in TRIZOL (Invitrogen) for isolation of RNA, according to the manufacturer's protocol. A two-step M-MLV Platinum SYBR Green qPCR SuperMix-UDG kit (Vazyme Biotech) was used to conduct reverse transcription and quantitative PCR. The primers for the genes (listed in Table S2), including Insulin1 , Pdx-1 , Mafa ,Heparanase (Hpse), Pparg (PPAR $\gamma$ ), Smad4, andLef1 , were synthesized by Invitrogen. The amount of each gene was determined according to the amount of GAPDH.

\section{Luciferase reporter gene assay}

Truncated heparanase promoters $(-2000-0,-1000-0,-300-0)$ were cloned forward of the luciferase reporter gene in a pGL3 basic vector, which was co-transfected with PPAR $r$ vectors into 293T cells using Lipofectamine 2000 (Invitrogen). Luciferase activity was detected with the Luciferase Reporter Assay System (Promega, Fitchburg, WI, USA), as previously described (Li et al. , 2019).

\section{Chromatin immunoprecipitation}

Chromatin immunoprecipitation assays were conducted according to the previously described protocol (Lin et al. , 2012). Briefly, MIN6 cells were lysed and sonicated to generate DNA fragments of 300-1000 nucleotides. Protein-linked DNA was immunoprecipitated with PPAR $\gamma$ antibody or control rabbit IgG, and the immunoprecipitated DNA sequence was then examined by quantitative PCR. The primers used in chromatin immunoprecipitation were listed in Table S2. The amount of the target DNA immunoprecipitated was normalized to a control input.

\section{Data and statistical analysis}

Data were represented as mean \pm SEM (Standard Error of Mean). In vitro experiments were repeated three times at least. GraphPad Prism 6.0 software (San Diego, CA, USA; RRID: SCR_002798) was used to perform statistical analysis. One-way ANOVA followed by Dunnett's post hoc test were used to assess the significant differences between multiple groups. $\mathrm{P}<0.05$ was considered statistically significant. The data and statistical analysis comply with the recommendations on experimental design and analysis in pharmacology (Curtis et al. , 2018).

\section{Results}

\section{Localization of HS in islets of normal and STZ-treated diabetic mice}

In this study, we used two HS antibodies to explore the detailed localization of HS in murine islets. The antibody reacts with 10E4 epitope of HS recognizes N-sulfated glucosamine residue of HS, while the 3G10 antibody reacts with a neo-epitope of HS, which is generated by heparitinase I digestion on sections (David et al. , 1992). The staining results of both 10E4 and 3G10 antibodies showed that HS was highly expressed in normal islets (Fig. 1A and 1B). However, minor differences were observed. The 10E4 antibody staining in control group only exists in intra-islets (Fig. 1A). The 3G10 antibody staining showed that HS was not only highly expressed in the islets, but also distributed in a net shape in the extracellular matrix around the pancreatic acinar cells (Fig. 1B). Double-fluorescence staining of HS with four islet endocrine hormones showed that 10E4 mainly expresses in insulin-positive beta cells but less in other types of islet endocrine 
cells, including glucagon-positive alpha cells, somatostatin-positive delta cells, and pancreatic polypeptide (PP)-positive PP cells (Fig. 1A), whereas 3G10 covers most islet endocrine cell types (Fig. 1B).

Obviously different expression patterns between 10E4 and 3G10 were found in STZ-treated mice. As in normal islets, 10E4 was co-localized with insulin, which is reduced with damage beta cells in STZ mice (Fig. 1A). Using 3G10 antibody, the amount of intra-islet HS was clearly decreased in the whole islets of STZ-treated mice, and HS exhibited a similar pattern of net shape to that in the peripheral acinar cells (Fig. 1B). It should be noticed that residual 3G10-stained HS could be still observed in alpha cells, delta cells, and PP cells in STZ mice (Fig. 1B).

Heparanase is highly expressed in pancreatic beta cells and monocytes in islets. Immunostaining showed that heparanase is expressed in islets rather than peripheral acinar cells (Fig. 2A and 2B). Remarkably, intra-islet content of heparanase is increased in STZ-treated mice, in which we noticed some cells had extremely higher expression of heparanase (Fig. 2A and 2B). We further analyzed the expression level of heparanase in different islet cell types from reported single cell sequencing data. Although the difference of heparanase expression between diabetic and normal samples was not significant due to limited sample number, it confirmed the expression of heparanase is high in the alpha and beta endocrine cells in the islets (Fig. 2C). To confirm this, double-immunofluorescence was used to investigate the detailed localization of heparanase in islets. In control mice, less F4/80-positive monocytes could be observed (Fig. 2D), heparanase was expressed in most insulin-positive beta cells (Fig. 2E). In contrast, heparanase was found to co-localized with F4/80-positive monocytes in STZ islets, and heparanase-positive cells was still present in islet without F4/80 (Fig. 2D). As shown in Fig. 2E, those F4/80-negative cells that expressed heparanase was co-localized with insulin.

\section{OGT2115 improves glucose profiles in STZ-induced diabetic mice}

The intra-islet HS loss was prevented by treatment with, a heparanase inhibitor, OGT2115 (Fig. 3A). The inhibitor was subcutaneously injected into STZ-induced diabetic mice daily. The entire procedure was depicted in Fig. 3B. After four weeks of administration, the random blood glucose of STZ mice treated with $10 \mathrm{mg} / \mathrm{kg}$ OGT2115 was significantly reduced when compared with vehicle-treated STZ mice (Fig. 3C). No alteration occurred in body weight (Fig. 3D) or in food intake (Fig. 3E). An intraperitoneal glucose tolerance test (IPGTT) showed that the OGT2115-treated STZ mice exhibited improved glucose tolerance when compared with the vehicle-treated group (Fig. 3F-G). During the IPGTT, the GSIS before and 30 min after glucose loading was increased in the STZ mice treated with either 3 or $10 \mathrm{mg} / \mathrm{kg}$ OGT2115 when compared with the vehicle-treated STZ mice (Fig. 3H).

\section{OGT2115 reduced apoptosis of islet beta cells in STZ mice}

Immunohistochemistry with an insulin antibody showed that STZ treatment clearly reduced intra-islet insulin content (Fig. 4A and 4B). However, administration of OGT2115 to STZ mice could partially improve the intra-islet insulin level (Fig. 4A and 4B). The ratio of insulin ${ }^{+} /$glucagon $^{+}$cells was increased significantly in the islets of $10 \mathrm{mg} / \mathrm{kg}$ OGT2115-treated STZ mice when compared to vehicle-treated STZ mice (Fig. 4A and 4C). TUNEL assays showed an obvious decrease in the number of apoptotic pancreatic beta cells in OGT2115treated STZ mice when compared with vehicle-treated STZ mice. Statistical analysis also confirmed the reduced apoptotic ratio in STZ mice treated with $10 \mathrm{mg} / \mathrm{kg}$ OGT2115 (Fig. 4D).

\section{OGT2115 prevented loss of intra-islet HS level and reduced infiltration of immunocytes in STZ mice}

To investigate whether the protective effect of OGT2115 on STZ-induced pancreatic beta cell damage was directly due to restoration of intra-islet HS levels, HS was stained with Alcian blue dye or HS antibody. As shown in Fig. 5A and 5B, the intra-islet HS was clearly lost in the STZ mice. By contrast, the STZ mice treated with either $3 \mathrm{mg} / \mathrm{kg}$ or $10 \mathrm{mg} / \mathrm{kg}$ OGT2115 showed a significant increase in intra-islet HS (Fig. 5A and Fig. 5B). Multiple low-dose injections of STZ caused beta cell death and could induce subsequent infiltration of F4/80-positive monocytes (Fig. 5A and 5C), CD8 or CD4-positive T cells (Fig. 5A and 5D). 
Quantitative analysis of F4/80, CD8, and CD4 positive cell numbers demonstrated a notable decrease in the infiltration of immunocytes in the islets of $10 \mathrm{mg} / \mathrm{kg}$ OGT2115-treated STZ mice when compared with vehicle-treated STZ mice (Fig. 5C and Fig. 5D).

\section{OGT2115 did not protect pancreatic beta cells from STZ -induced dysfunction in vitro}

We used the mouse insulinoma MIN6 cell line and primary isolated murine islets to test whether OGT2115 had a protective effect in cultured beta cells in vitro. The MTT assay showed that a high dosage of OGT2115 (more than $10 \mu \mathrm{M}$ ) could significantly disrupt the viability of MIN6 cells (IC50=10.31 $\mu \mathrm{M}$, Fig. $6 \mathrm{~A})$. Concentrations of up to $1 \mu \mathrm{M}$ OGT2115 were used in further in vitro experiments. STZ reduced the viability of MIN6 cells after a $24 \mathrm{~h}$ incubation. However, co-incubation with OGT2115 did not prevent the damage by STZ (Fig. 6B) on MIN6 cells. Likewise, OGT2115 did not protect against STZ-induced damage in the GSIS of cultured islets (Fig. 6C). The STZ- induced reduction in mRNA level of genes involved in insulin expression and secretion, includinginsulin , $P d x-1$ and Mafa, were not improved by OGT2115 treatment of cultured islets (Fig. 6D).

\section{High glucose but not STZ increased heparanase expression in cultured islets}

In vitro, chronic $(24 \mathrm{~h})$ incubation in glucose dose-dependently stimulated heparanase expression in cultured islets (Fig. 6E), whereas STZ treatment did not altered heparanase expression (Fig. 6F). We further screened the mRNA expression of transcriptional factors that were associated with the mRNA transcription of Heparanase. After a $24 \mathrm{~h}$ incubation with $25 \mathrm{mmol} / \mathrm{L}$ glucose, the expression of Ppargwas reduced, while p53 , Egr1 , and Ets1 were increased when compared with islets treated with $11.1 \mathrm{mmol} / \mathrm{L}$ glucose (Fig. $6 \mathrm{H})$. By contrast, the expression of Smad4, Lef1 and Tgli1 was not altered by incubation with $25 \mathrm{mmol} / \mathrm{L}$ glucose for $24 \mathrm{~h}$ (Fig. 6G).

\section{ППАРҮ $\beta_{\gamma}$}

Chronic high glucose stimulation caused increased heparanase and declined PPAR $\gamma$ expression, which suggested that PPAR $\gamma$ acted as a transcription repressor for Heparanase. As shown in Fig. 7A, we found three predicted binding sites of PPAR $\gamma$ in the promoter region (defined as 2000 bases forward transcriptional start site (TSS) of gene) of the murine Heparanase gene from the JASPAR database (http://jaspar.genereg.net/) according to the scanning score. These binding sites were identified as peroxisome proliferator responsive elements (PPRE), including PPRE1 (5'-GGAGGTGACAGGTGA-3', -1567/1552), PPRE2 (5'-CCTGGGCAGAGGCA-3', -442/-427), and PPRE3 (5'-TTAAGGCAGAAGGGA-3', 384/-369). The predicted sequence of PPRE in the JASPAR database was shown in Fig. 7B. We then performed luciferase reporter gene tests to detect whether PPAR $\curlyvee$ could bind to these promoter regions of the Heparanase gene. As shown in Fig. 7C, the whole construct (2000 bases forward TSS, -2000/0) was able to significantly drive expression of the luciferase reporter gene in $293 \mathrm{~T}$ cells (Fig. 7C). By contrast, the activity of luciferase was dose-dependently inhibited by a PPAR $\gamma$ agonist rosiglitazone (ROSI, Fig. 7C). The region of these three predicted binding sites that could bind PPAR $\gamma$ were further investigated by determining the sequential 5'-deletion constructs from p-1000 (-1000/0). A higher expression of the luciferase reporter gene suggested an enhanced expression after deletion of PPRE1. However, fluorescence could be also inhibited by rosiglitazone (Fig. 7C). After the promoter region was cut to 300 bases length (-300/0), the transcriptional activity was abolished (Fig. 7C), suggesting a cooperation of PPRE1, PPRE2, and PPRE3 in the regulation of Heparanase gene expression. Similarly, chromatin immunoprecipitation (CHIP) confirmed that the PCR product from the chromatin pulled down by an anti-PPAR $\gamma$ antibody corresponded to the predicted Heparanase gene promoter region (Fig. 7D).

\section{Discussion}

Intra-islet HS was previously reported to be involved in beta cell dysfunction in autoimmune diabetes (Simeonovic et al. , 2013), islet amyloid formation, and islet amyloid polypeptide-induced islet cell apoptosis (Oskarsson et al. , 2015). In addition, some important genes that participate in insulin secretion, like BETA2/NeuroD (Noguchi et al. , 2007) and pancreatic and duodenal homeobox factor 1 (PDX1) (Ueda et 
$a l$. , 2008), could be regulated by cell surface HSPG. In addition, murine islets selectively lose HS to 11-27\% of normal levels during primary isolation before islet transplantation (Choong et al. , 2015). These data suggest that the maintenance of intra-islet HS level is important to the function of islets.

However, the mechanism of the protective effect of HS on beta cells is still unclear. First, we detected the distribution of HS in the islets from normal and STZ-treated mice. Previous study suggested that perlecan, one important type of HSPG, is localized in the peri-islet and surrounding intra-islet capillaries and is destroyed in the islets of NOD mice (Irving-Rodgers et al. , 2008). Takahashi et al., using anti-HS antibody (3G10 site) and immunohistochemistry, found that HS is significantly expressed in the insulin-positive beta cells but not in glucagon-positive alpha cells of islets (Takahashi et al. , 2009). In the present study, we precisely showed that 10E4 epitope mainly exists in islet beta cells but less expresses in other type of islet cells, which is similar from that of a previous study using anti-10E4 antibody, where HS co-localized with insulin but not glucagon staining in the normal human islets (Simeonovicet al. , 2018). However, after use heparitinase-treatment to expose the 3G10 epitope of HS, we found that 3G10 staining was not only highly co-localized with beta cells, but also colocalized with other type of islet endocrine cells in greater amounts than peripheral acinar cells. This difference may indicate different sites of HS antigen have distinct patterns in pancreatic islets (Theodoraki et al. , 2015). Importantly, in STZ mice, 10E4 staining remains a similar pattern with insulin-positive cells, confirmed that 10E4 could be a beta cell-specific HS epitope. In contrast, 3G10 staining is lost in most beta cells of STZ mice, which exhibits a similar net shape as that in the peripheral acinar cells. Unlike 10E4 data, 3G10 result provided stronger mark of intra-islet HS loss. Although the detailed distribution pattern of HS in the islets should be further investigated in more species, like the data from the islets from NOD mice (Irving-Rodgerset al. , 2008) and from patients with type 1 diabetes (Simeonovicet al. , 2018), the intra-islet HS is obviously lost in STZ-treated diabetic mice, it seems clear that HS is highly expressed in the normal islets, where it performs critical biological roles, especially in pancreatic beta cells.

Since the loss of intra-islet HS could be a marker of type 1 diabetes progression in both patients and animal models, it is worthful to further investigate its underlying mechanism. As an endoglucuronidase, heparanase could specifically cleave the glycosidic bond of GlcA-GlcNS in HS, thereby promoting the degradation of HS (Mao et al. , 2014). In many cancers, high expression of heparanase could enhance the hydrolysis of HS in the extracellular matrix to promote tumor invasion, metastasis, and angiogenesis (Dai et al. , 2017). Thus, heparanase inhibitors, including sulfated polysaccharides/oligosaccharides (HS analogs), antiheparanase antibodies, nucleic acid-based inhibitors, and small molecules, have been developed to treat cancer and other rare diseases (Rivara et al. , 2016). Ziolkowski et al. found that PI-88, an analog of HS, inhibited heparanase and improved intra-islet HS level to protect against islet dysfunction in NOD mice (Ziolkowskiet al. , 2012). In line with this evidence, our data showed that a small molecular heparanase inhibitor, OGT2115 (Courtney et al. , 2005), not only protects islet beta cells from STZ-induced apoptosis, but also improves glucose profiles and increases insulin secretion in STZ-induced diabetic mice by preventing the loss of intra-islet HS. It is known that the onset age and morbidity of NOD mice are uncertain (Acharjee et al. , 2013), this multiple injection of low dose STZ-induced diabetic model could be reliable in the pharmacological study of heparanase inhibitors as anti-diabetic drugs. Furthermore, morphological staining confirms a significant reduction in the infiltration of immunocytes in the islets of OGT2115-treated STZ mice. In view of the important role of immune inflammatory damage in the process of beta cell injury in type 1 diabetes (Lombardi et al. , 2018), the decrease in intra-islet immunocytes infiltration in this STZ-induced diabetic mouse model may be vital for improved glucose control in OGT2115-treated STZ mice.

Interestingly, OGT2115 does not reduce STZ-induced beta cell dysfunction in vitro, suggested that preventing HS loss in beta cells by OGT2115 could not directly prevent STZ-induced beta cell damage. In vitro , STZ is transported into beta cells via glucose transporter 2 (GLUT2), thereby directly damaging beta cells (Deshpande et al. , 2019). However, in the present in vivo experiment, infiltration of the recruited inflammatory cells in the islets is the main mechanism of induction of diabetes by multiple low-dose injections of STZ (Yanget al. , 2003). Therefore, we focused the in vivoinhibitory effect of OGT2115 on increased intra-islet heparanase level in STZ mice. Heparanase was previously reported to be upregulated by high 
glucose in renal epithelial cells (Maxhimer et al. , 2005) and retinal microvascular endothelial cells (Hu et al. , 2017), and urine and plasma heparanase level are associated with blood glucose levels in patients with diabetes (Shafat et al. , 2011). A reduction in heparanase activity prevents the high glucose-induced epithelial-mesenchymal transition (Masola et al. , 2017). We speculate that heparanase level is also increased in STZ-induced hyperglycemic mice and that heparanase subsequently hydrolyzes intra-islet HS to aggravate islet damage under an inflammatory microenvironment. In line with this hypothesis, higher intra-islet heparanase expression is found in STZ mice than in control mice. Previous study showed that heparanase is strongly expressed in monocytes in diabetes-onset NOD pancreas, while weak cell surface expression of heparanase could be also observed (Ziolkowski et al. , 2012). Using a commercial heparanase antibody that recognizes $65 \mathrm{kD}$ precursor as well as $50 \mathrm{kD}$ and $8 \mathrm{kD}$ subunits of heparanase I, we found that although heparanase is highly expressed in not only F4/80-positive macrophages, but also obvious heparanase staining could be observed in murine islet beta cells. The expression of heparanase in beta cells was confirmed by bioinformatic analysis of single cell sequencing data of human and mice islets from GEO database (Xin et al. , 2016; Lawloret al. , 2017; Sharon et al. , 2019). Together, these results at least suggest that heparanase is also highly expressed in islet cells, and this beta cell-expressed heparanase may contribute to wide-spread loss of HS in STZ islets as 3G10 staining indicated.

How glucose regulates the expression of heparanase is not fully understood. ROS is reported to mediate high glucose-induced heparanase expression (Han et al. , 2007; Rao et al. , 2011). The promoter region of heparanase contains GC-rich sequences and lacks TATA or CCAAT box (Dong et al. , 2000). In addition, some factors, including nuclear factor- $\varkappa \mathrm{B}(\mathrm{NF}-\varkappa \mathrm{B})$ (Hao et al. , 2015; Anet al. , 2018), forkhead box protein O4 (An et al. , 2011), early growth response gene 1 (EGR1) (de Mestre et al. , 2005), truncated gliomaassociated oncogene homolog 1 (TGLI1) (Zhu et al. , 2014), and ETS1 (Lu et al. , 2003) can up-regulate heparanase expression in many cancers; while tumor suppressor p53 (Barazet al. , 2006), SMAD family member 4 (SMAD4) and lymphoid enhancer binding factor 1 (LEF1) (Qu et al. , 2016), are reported to down-regulate heparanase expression. Here, we verified that chronic high glucose has less effect on the expression of SMAD4, LEF1 and TGLI1 in cultured islets, while the expression of ETS1, EGR1, and p53 are increased. Notably, the expression of PPAR $\gamma$ is significantly reduced in high glucose-treated islets. In line with this result, our previous study has showed that high glucose-treated islets have an increased ETS1 expression to injury beta cell function (Chen et al. , 2016). Decreased PPAR $\curlyvee$ expression is also reported in high glucose-treated islets (So et al. , 2013). In addition, activation of PPAR $\gamma$ is reported to downregulate the expression of heparanase to inhibit hepatocellular carcinoma metastases (Shen et al. , 2012). We further confirmed that the direct binding of PPAR $\gamma$ to the promoter region negatively regulates the transcriptional activity of the heparanase gene. Thus, PPAR $\gamma$ may act as an important inhibitory transcription factor, together with other stimulating factors like ETS1 or EGR1, thereby involves in hyperglycemia-stimulated heparanase expression.

To summarize, STZ-induced hyperglycemia in mice decreases the expression of PPAR $\gamma$ in the islets, thereby eliminating the occupancy of the heparanase promoter region and stimulating the expression of heparanase. Increased heparanase hydrolyzes intra-islet HS, which promotes infiltration of immunocytes, damages beta cells and, subsequently aggravates hyperglycemia in type 1 diabetes. Although further experiments are needed to improve the knowledge of the underlying mechanisms, this study provided pharmacological evidence that the use of a heparanase inhibitor could prevent the loss of intra-islet HS, thereby providing a protective effect on islet function in the process of type 1 diabetes.

\section{Acknowledgements:}

This work was supported by the National Natural Science Foundation $(81420108007,81603169,81900703$, and 81600598), the Natural Science Foundation of Jiangsu Province (BK20161027), the Natural Science Research Program for Higher Education in Jiangsu Province (16KJB310007), the Key Project of Science and Technology Development Fund of Nanjing Medical University (2015NJMUZD016), the China Postdoctoral Science Foundation Funded Project (2017M611869).

\section{Declaration of Interests}


The authors declare no competing interests.

\section{Author contributions}

Conceptualization, Xiao Han, Peng Sun; Methodology, Wen-Yu Song, Xiao-Han Jiang, Kai Li, Yan Wang, Yun Xia, Ming-Xuan Zhou, Chen-Yu Zhang, Chong-Chong Yin, Chen Qiu, Ying Ding; Investigation, WenYu Song, Xiao-Han Jiang, Kai Li; Writing - Original Draft, Wen-Yu Song, Peng Sun, Kai Li, Xiao-Han Jiang; Supervision, Peng Sun, Xiao Han.

\section{Declaration of transparency and scientific rigour}

This Declaration acknowledges that this paper adheres to the principles for transparent reporting and scientific rigour of preclinical research as stated in the BJP guidelines for Design \& Analysis and Animal Experimentation and as recommended by funding agencies, publishers, and other organisations engaged with supporting research.

\section{References}

Acharjee S, Ghosh B, Al-Dhubiab BE, Nair AB (2013). Understanding type 1 diabetes: etiology and models. Canadian journal of diabetes 37 (4): 269-276.

An X, Zhang L, Yao Q, Li L, Wang B, Zhang J, et al. (2018). The receptor for advanced glycation endproducts mediates podocyte heparanase expression through NF-kappaB signaling pathway. Molecular and cellular endocrinology 470: 14-25.

An XF, Zhou L, Jiang PJ, Yan M, Huang YJ, Zhang SN, et al.(2011). Advanced glycation end-products induce heparanase expression in endothelial cells by the receptor for advanced glycation end products and through activation of the FOXO4 transcription factor. Molecular and cellular biochemistry 354 (1-2):47-55.

Baraz L, Haupt Y, Elkin M, Peretz T, Vlodavsky I (2006). Tumor suppressor p53 regulates heparanase gene expression. Oncogene 25 (28): 3939-3947.

Chen F, Sha M, Wang Y, Wu T, Shan W, Liu J, et al. (2016). Transcription factor Ets-1 links glucotoxicity to pancreatic beta cell dysfunction through inhibiting PDX-1 expression in rodent models.Diabetologia $\mathbf{5 9}$ (2): $316-324$.

Choong FJ, Freeman C, Parish CR, Simeonovic CJ (2015). Islet heparan sulfate but not heparan sulfate proteoglycan core protein is lost during islet isolation and undergoes recovery post-islet transplantation.American journal of transplantation : official journal of the American Society of Transplantation and the American Society of Transplant Surgeons 15 (11): 2851-2864.

Courtney SM, Hay PA, Buck RT, Colville CS, Phillips DJ, Scopes DI, et al. (2005). Furanyl-1,3-thiazol-2-yl and benzoxazol-5-yl acetic acid derivatives: novel classes of heparanase inhibitor. Bioorganic $\mathcal{E}$ medicinal chemistry letters 15 (9): 2295-2299.

Curtis MJ, Alexander S, Cirino G, Docherty JR, George CH, Giembycz MA, et al. (2018). Experimental design and analysis and their reporting II: updated and simplified guidance for authors and peer reviewers. Br J Pharmacol 175 (7): 987-993.

Dai X, Yan J, Fu X, Pan Q, Sun D, Xu Y, et al. (2017). Aspirin Inhibits Cancer Metastasis and Angiogenesis via Targeting Heparanase.Clinical cancer research : an official journal of the American Association for Cancer Research 23 (20): 6267-6278.

David G, Bai XM, Van der Schueren B, Cassiman JJ, Van den Berghe H (1992). Developmental changes in heparan sulfate expression: in situ detection with mAbs. The Journal of cell biology119 (4): 961-975.

de Mestre AM, Rao S, Hornby JR, Soe-Htwe T, Khachigian LM, Hulett MD (2005). Early growth response gene 1 (EGR1) regulates heparanase gene transcription in tumor cells. The Journal of biological chemistry 280 (42): 35136-35147. 
Deshpande AS, Ramireddy S, Sudandiradoss C, Noor A, Sen P (2019). Streptozocin; a GLUT2 binding drug, interacts with human serum albumin at loci h6DOM3-h7DOM3. International journal of biological macromolecules 128: 923-933.

Dong J, Kukula AK, Toyoshima M, Nakajima M (2000). Genomic organization and chromosome localization of the newly identified human heparanase gene. Gene 253 (2): 171-178.

Edge AS, Spiro RG (2000). A specific structural alteration in the heparan sulphate of human glomerular basement membrane in diabetes.Diabetologia 43 (8): 1056-1059.

Ferris ST, Carrero JA, Mohan JF, Calderon B, Murphy KM, Unanue ER (2014). A minor subset of Batf3dependent antigen-presenting cells in islets of Langerhans is essential for the development of autoimmune diabetes. Immunity 41 (4): 657-669.

Ginath S, Lurie S, Golan A, Amsterdam A, Sandbank J, Sadan O, et al. (2015). The expression of heparanase in normal and preeclamptic placentas. J Matern Fetal Neonatal Med 28 (13):1589-1593.

Han J, Woytowich AE, Mandal AK, Hiebert LM (2007). Heparanase upregulation in high glucose-treated endothelial cells is prevented by insulin and heparin. Experimental biology and medicine 232 (7): 927-934.

Han X, Sun Y, Scott S, Bleich D (2001). Tissue inhibitor of metalloproteinase-1 prevents cytokine-mediated dysfunction and cytotoxicity in pancreatic islets and beta-cells. Diabetes50 (5): 1047-1055.

Hao NB, Tang B, Wang GZ, Xie R, Hu CJ, Wang SM, et al. (2015). Hepatocyte growth factor (HGF) upregulates heparanase expression via the $\mathrm{PI} 3 \mathrm{~K} / \mathrm{Akt} / \mathrm{NF}-\mathrm{kappaB}$ signaling pathway for gastric cancer metastasis. Cancer letters 361 (1): 57-66.

Hu J, Wang J, Leng X, Hu Y, Shen H, Song X (2017). Heparanase mediates vascular endothelial growth factor gene transcription in high-glucose human retinal microvascular endothelial cells. Molecular vision 23: 579-587.

Iozzo RV (1998). Matrix proteoglycans: from molecular design to cellular function. Annu Rev Biochem 67: $609-652$

Irving-Rodgers HF, Ziolkowski AF, Parish CR, Sado Y, Ninomiya Y, Simeonovic CJ, et al. (2008). Molecular composition of the peri-islet basement membrane in NOD mice: a barrier against destructive insulitis. Diabetologia 51 (9): 1680-1688.

Lawlor N, George J, Bolisetty M, Kursawe R, Sun L, Sivakamasundari V, et al. (2017). Single-cell transcriptomes identify human islet cell signatures and reveal cell-type-specific expression changes in type 2 diabetes. Genome Res 27 (2): 208-222.

Li K, Qiu C, Sun P, Liu DC, Wu TJ, Wang K, et al. (2019). Ets1-Mediated Acetylation of FoxO1 Is Critical for Gluconeogenesis Regulation during Feed-Fast Cycles. Cell reports26 (11): 2998-3010 e2995.

Lin HY, Yin Y, Zhang JX, Xuan H, Zheng Y, Zhan SS, et al. (2012). Identification of direct forkhead box $\mathrm{O} 1$ targets involved in palmitate-induced apoptosis in clonal insulin-secreting cells using chromatin immunoprecipitation coupled to DNA selection and ligation.Diabetologia 55 (10): 2703-2712.

Lin M, Yin N, Murphy B, Medof ME, Segerer S, Heeger PS, et al.(2010). Immune cell-derived c3 is required for autoimmune diabetes induced by multiple low doses of streptozotocin. Diabetes 59 (9): 2247-2252.

Lombardi A, Tsomos E, Hammerstad SS, Tomer Y (2018). Interferon alpha: The key trigger of type 1 diabetes. Journal of autoimmunity94: 7-15.

Lu WC, Liu YN, Kang BB, Chen JH (2003). Trans-activation of heparanase promoter by ETS transcription factors. Oncogene 22 (6): 919-923.

Mallone R, Brezar V, Boitard C (2011). T cell recognition of autoantigens in human type 1 diabetes: clinical perspectives. Clinical \& developmental immunology 2011: 513210. 
Mao Y, Huang Y, Buczek-Thomas JA, Ethen CM, Nugent MA, Wu ZL, et al. (2014). A liquid chromatography-mass spectrometry-based approach to characterize the substrate specificity of mammalian heparanase. The Journal of biological chemistry 289 (49):34141-34151.

Masola V, Granata S, Bellin G, Gambaro G, Onisto M, Rugiu C, et al. (2017). Specific heparanase inhibition reverses glucose-induced mesothelial-to-mesenchymal transition. Nephrology, dialysis, transplantation : official publication of the European Dialysis and Transplant Association - European Renal Association32 (7): $1145-1154$.

Maxhimer JB, Somenek M, Rao G, Pesce CE, Baldwin D, Jr., Gattuso P, et al. (2005). Heparanase-1 gene expression and regulation by high glucose in renal epithelial cells: a potential role in the pathogenesis of proteinuria in diabetic patients. Diabetes54 (7): 2172-2178.

Noble JA (2015). Immunogenetics of type 1 diabetes: A comprehensive review. J Autoimmun 64: 101-112.

Noguchi H, Ueda M, Matsumoto S, Kobayashi N, Hayashi S (2007). BETA2/NeuroD protein transduction requires cell surface heparan sulfate proteoglycans. Human gene therapy 18 (1): 10-17.

Oskarsson ME, Singh K, Wang J, Vlodavsky I, Li JP, Westermark GT (2015). Heparan Sulfate Proteoglycans Are Important for Islet Amyloid Formation and Islet Amyloid Polypeptide-induced Apoptosis. The Journal of biological chemistry 290 (24): 15121-15132.

Qu H, Zheng L, Jiao W, Mei H, Li D, Song H, et al. (2016). Smad4 suppresses the tumorigenesis and aggressiveness of neuroblastoma through repressing the expression of heparanase. Scientific reports6: 32628.

Rao G, Ding HG, Huang W, Le D, Maxhimer JB, Oosterhof A, et al.(2011). Reactive oxygen species mediate high glucose-induced heparanase-1 production and heparan sulphate proteoglycan degradation in human and rat endothelial cells: a potential role in the pathogenesis of atherosclerosis. Diabetologia 54 (6): 1527-1538.

Rivara S, Milazzo FM, Giannini G (2016). Heparanase: a rainbow pharmacological target associated to multiple pathologies including rare diseases. Future medicinal chemistry 8 (6):647-680.

Shafat I, Ilan N, Zoabi S, Vlodavsky I, Nakhoul F (2011). Heparanase levels are elevated in the urine and plasma of type 2 diabetes patients and associate with blood glucose levels. PloS one6 (2): e17312.

Sharon N, Chawla R, Mueller J, Vanderhooft J, Whitehorn LJ, Rosenthal B, et al. (2019). A Peninsular Structure Coordinates Asynchronous Differentiation with Morphogenesis to Generate Pancreatic Islets. Cell 176 (4): 790-804 e713.

Shen B, Chu ES, Zhao G, Man K, Wu CW, Cheng JT, et al. (2012). PPARgamma inhibits hepatocellular carcinoma metastases in vitro and in mice. British journal of cancer 106 (9):1486-1494.

Simeonovic CJ, Popp SK, Starrs LM, Brown DJ, Ziolkowski AF, Ludwig B, et al. (2018). Loss of intra-islet heparan sulfate is a highly sensitive marker of type 1 diabetes progression in humans. PloS one $\mathbf{1 3}$ (2): e0191360.

Simeonovic CJ, Ziolkowski AF, Wu Z, Choong FJ, Freeman C, Parish CR (2013). Heparanase and autoimmune diabetes. Frontiers in immunology 4: 471.

So WY, Cheng Q, Chen L, Evans-Molina C, Xu A, Lam KS, et al.(2013). High glucose represses betaklotho expression and impairs fibroblast growth factor 21 action in mouse pancreatic islets: involvement of peroxisome proliferator-activated receptor gamma signaling. Diabetes 62 (11): 3751-3759.

Sun P, Wang T, Chen L, Yu BW, Jia Q, Chen KX, et al. (2016). Trimer procyanidin oligomers contribute to the protective effects of cinnamon extracts on pancreatic beta-cells in vitro. Acta pharmacologica Sinica 37 (8): 1083-1090.

Sun P, Zhu JJ, Wang T, Huang Q, Zhou YR, Yu BW, et al. (2018). Benzbromarone aggravates hepatic 
steatosis in obese individuals.Biochimica et biophysica acta. Molecular basis of disease1864 (6 Pt A): 20672077 .

Takahashi I, Noguchi N, Nata K, Yamada S, Kaneiwa T, Mizumoto S, et al. (2009). Important role of heparan sulfate in postnatal islet growth and insulin secretion. Biochem Biophys Res Commun383 (1): 113-118.

Theodoraki A, Hu Y, Poopalasundaram S, Oosterhof A, Guimond SE, Disterer P, et al. (2015). Distinct patterns of heparan sulphate in pancreatic islets suggest novel roles in paracrine islet regulation. Mol Cell Endocrinol 399: 296-310.

Ueda M, Matsumoto S, Hayashi S, Kobayashi N, Noguchi H (2008). Cell surface heparan sulfate proteoglycans mediate the internalization of PDX-1 protein. Cell transplantation 17 (1-2):91-97.

Whitehead MJ, McGonigal R, Willison HJ, Barnett SC (2018). Heparanase attenuates axon degeneration following sciatic nerve transection.Sci Rep 8 (1): 5219.

Xin Y, Kim J, Okamoto H, Ni M, Wei Y, Adler C, et al. (2016). RNA Sequencing of Single Human Islet Cells Reveals Type 2 Diabetes Genes. Cell Metab 24 (4): 608-615.

Yang Z, Chen M, Fialkow LB, Ellett JD, Wu R, Nadler JL (2003). The novel anti-inflammatory compound, lisofylline, prevents diabetes in multiple low-dose streptozotocin-treated mice. Pancreas 26 (4): e99-104.

Zhu H, Carpenter RL, Han W, Lo HW (2014). The GLI1 splice variant TGLI1 promotes glioblastoma angiogenesis and growth. Cancer letters 343 (1): 51-61.

Ziolkowski AF, Popp SK, Freeman C, Parish CR, Simeonovic CJ (2012). Heparan sulfate and heparanase play key roles in mouse beta cell survival and autoimmune diabetes. The Journal of clinical investigation 122 (1): 132-141.
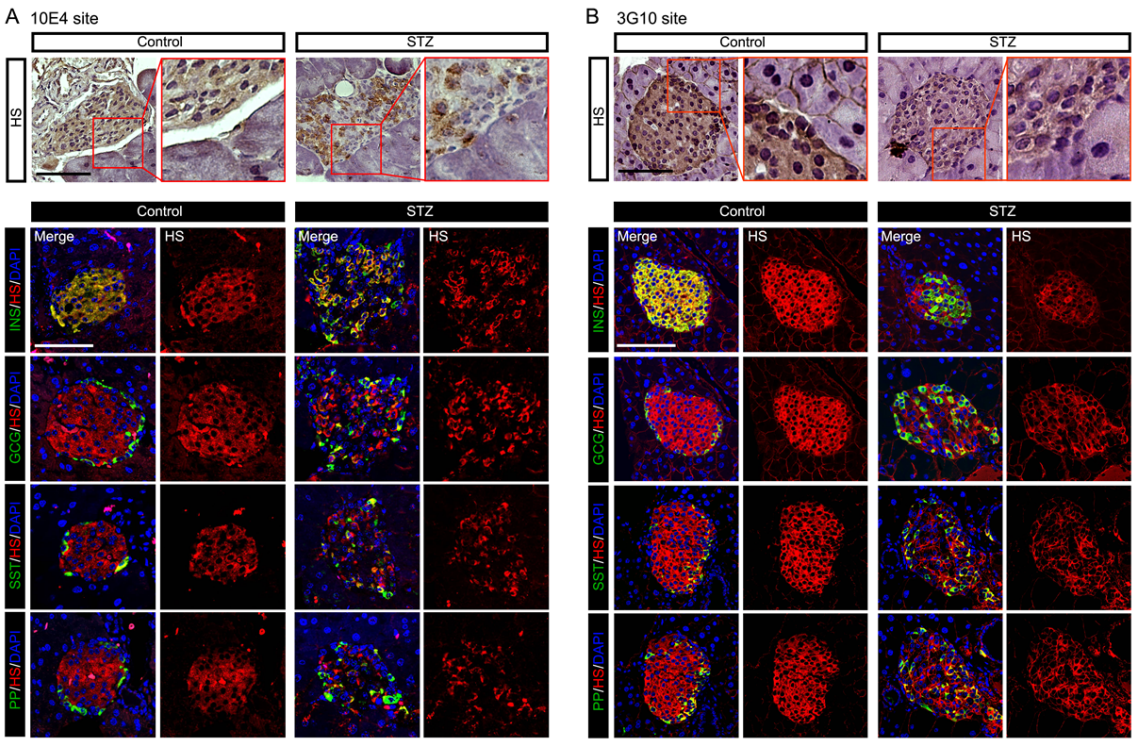

Figure 1. Location of intra-islet heparin sulfate (HS) in control and streptozotocin (STZ)induced diabetic mice. HS antibodies react with 10E4 [US Biological Cat\# H1890, RRID:AB_10013601] (A) or 3G10 (B) epitope. Representative images of HS immunohistochemical staining, HS and insulin (INS), glucagon (GCG), pancreatic polypeptide (PP), somatostatin (SST) staining in islets from control and STZ mice. Immunofluorescence followed by DAPI staining. Scale bar, $50 \mu \mathrm{m}$. 
A
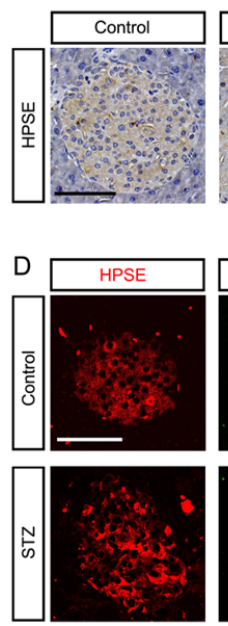
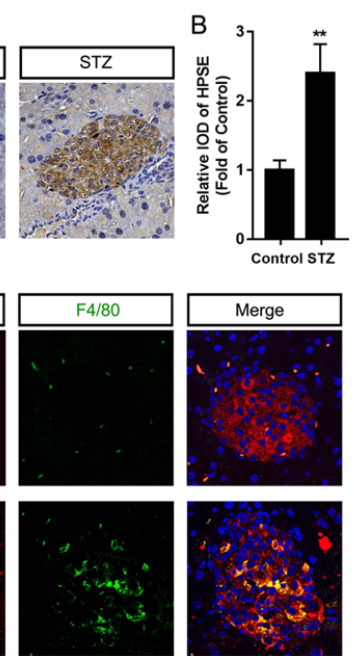
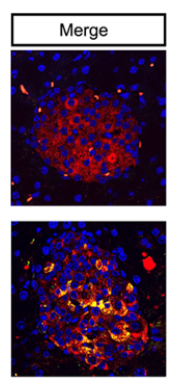

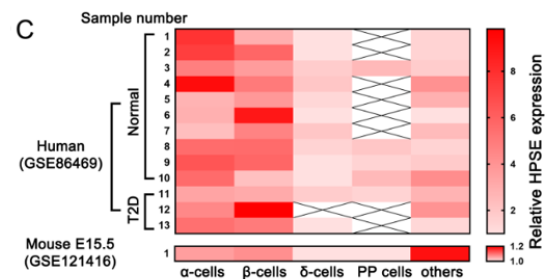

E
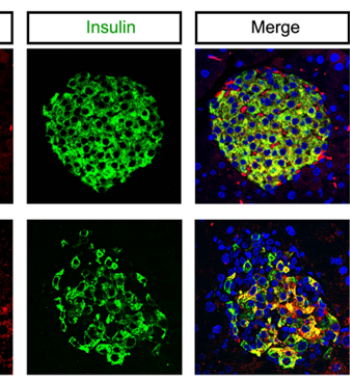

Figure 2. The expression and localization of intra-islet heparanase (HPSE) in control and streptozotocin (STZ)-induced diabetic mice. (A) Representative images of HPSE immunohistochemical staining of the islets in control and STZ mice. Scale bar $=50 \mu \mathrm{m}$. (B) Integral optical density (IOD) of HPSE immunohistochemical staining based on islet area in control and STZ mice, ${ }^{* *} \mathrm{p}<0.01, \mathrm{n}=10$. (C) The expression of HPSE in different islet cell types from single cell sequencing data. (D) Representative images of HPSE and monocytes (F4/80) staining, (E) HPSE and insulin staining in islets from control and STZ mice. Immunofluorescence followed by DAPI staining. Scale bar, $50 \mu \mathrm{m}$.
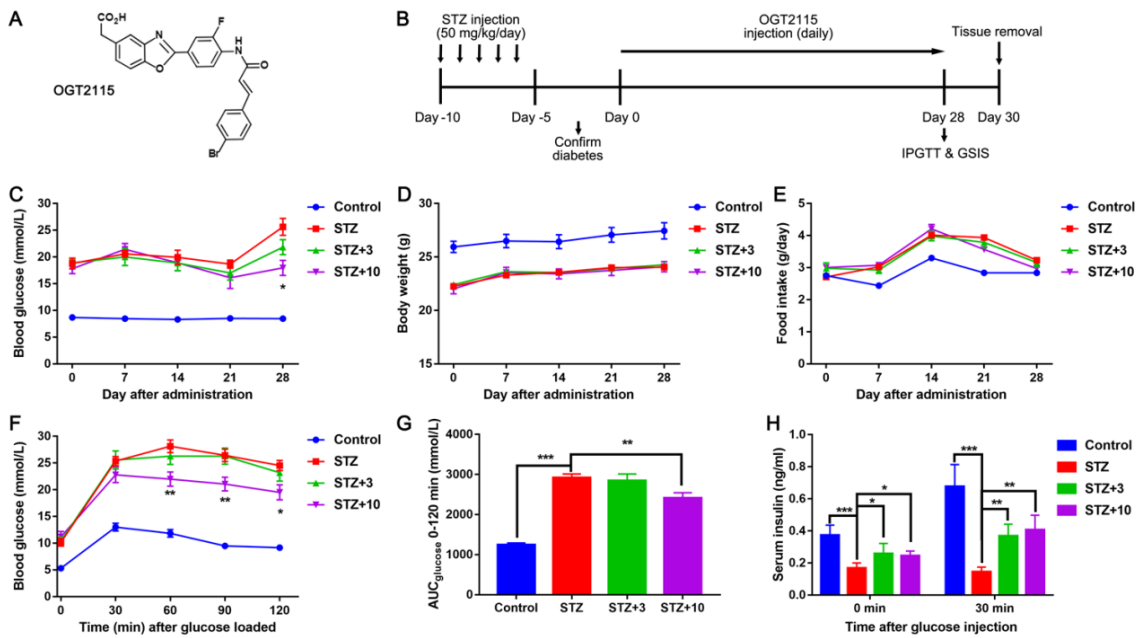

Figure 3. OGT2115 improved glycemic control in STZ-induced diabetic mice. (A) The structure of OGT2115. (B) The animal experiment procedure. (C) Random blood glucose levels after experimental administration of OGT2115. (D) Body weight after administration. (E) Food intake after administration. (F) Four weeks after OGT2115 administration, the blood glucose concentration during an intraperitoneal glucose tolerance test (IPGTT). ${ }^{*} \mathrm{p}<0.05,{ }^{*} \mathrm{p}<0.01$ compared to STZ group, $\mathrm{n}=10$. (G) AUC of the IPGTT curves. (H) Plasma insulin levels before and $30 \mathrm{~min}$ after glucose injection during the IPGTT, ${ }^{*} \mathrm{p}<0.05$, $* * \mathrm{p}<0.01,{ }^{* * *} \mathrm{p}<0.001$ as indicated, $\mathrm{n}=10$. 

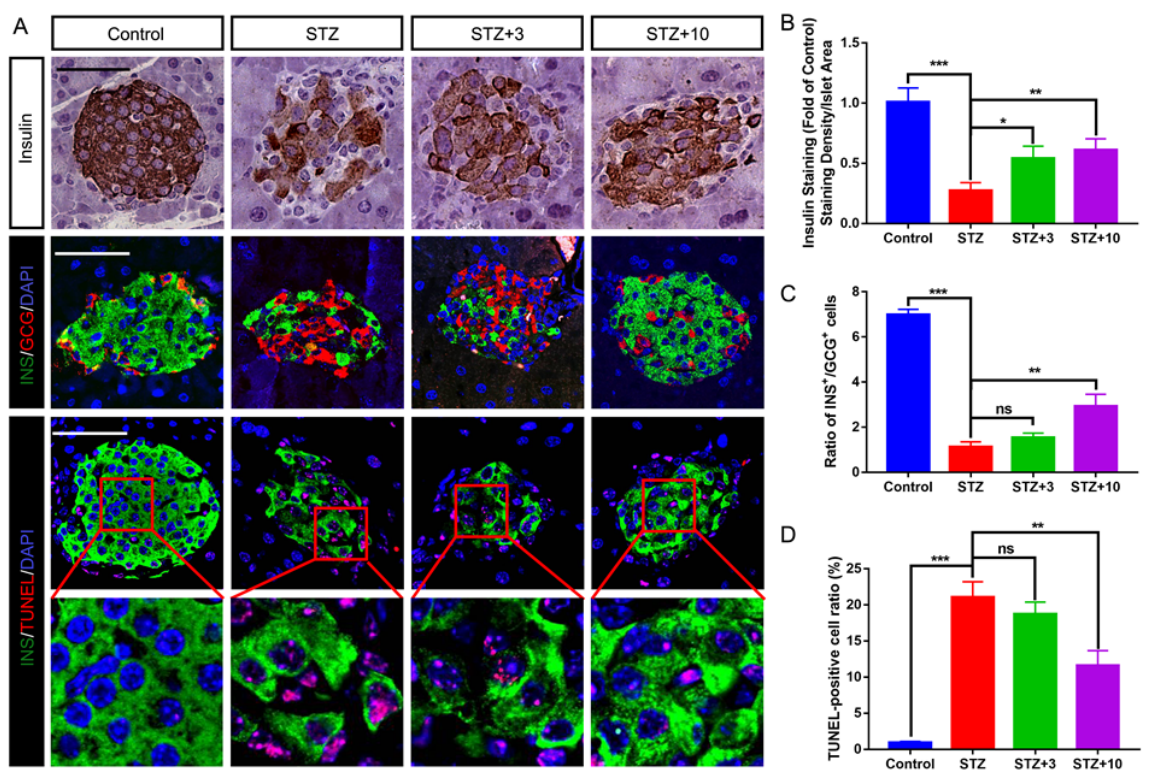

Figure 4. OGT2115 reduced apoptosis of islet beta cells in STZ mice . (A) Insulin immunohistochemical staining, insulin (INS)/glucagon (GCG) ratios, and TUNEL/insulin double-immunofluorescence staining in islets administered with different doses of OGT2115. Nuclei were stained with DAPI. Scale bar $=50 \mu \mathrm{m}$. (B) Intensity of insulin immunohistochemical staining based on islet area. (C) Ratio of insulin positive $\left(\mathrm{INS}^{+}\right)$cells over glucagon positive $\left(\mathrm{GCG}^{+}\right)$cells in the islets of the different treatment groups. (D) Percentage of TUNEL/insulin positive cells over insulin positive cells in the islets of the different treatment groups. ${ }^{*} \mathrm{p}<0.05,{ }^{*} \mathrm{p}<0.01,{ }^{* * *} \mathrm{p}<0.001, \mathrm{~ns}=$ not significant as indicated, $\mathrm{n}=10$.
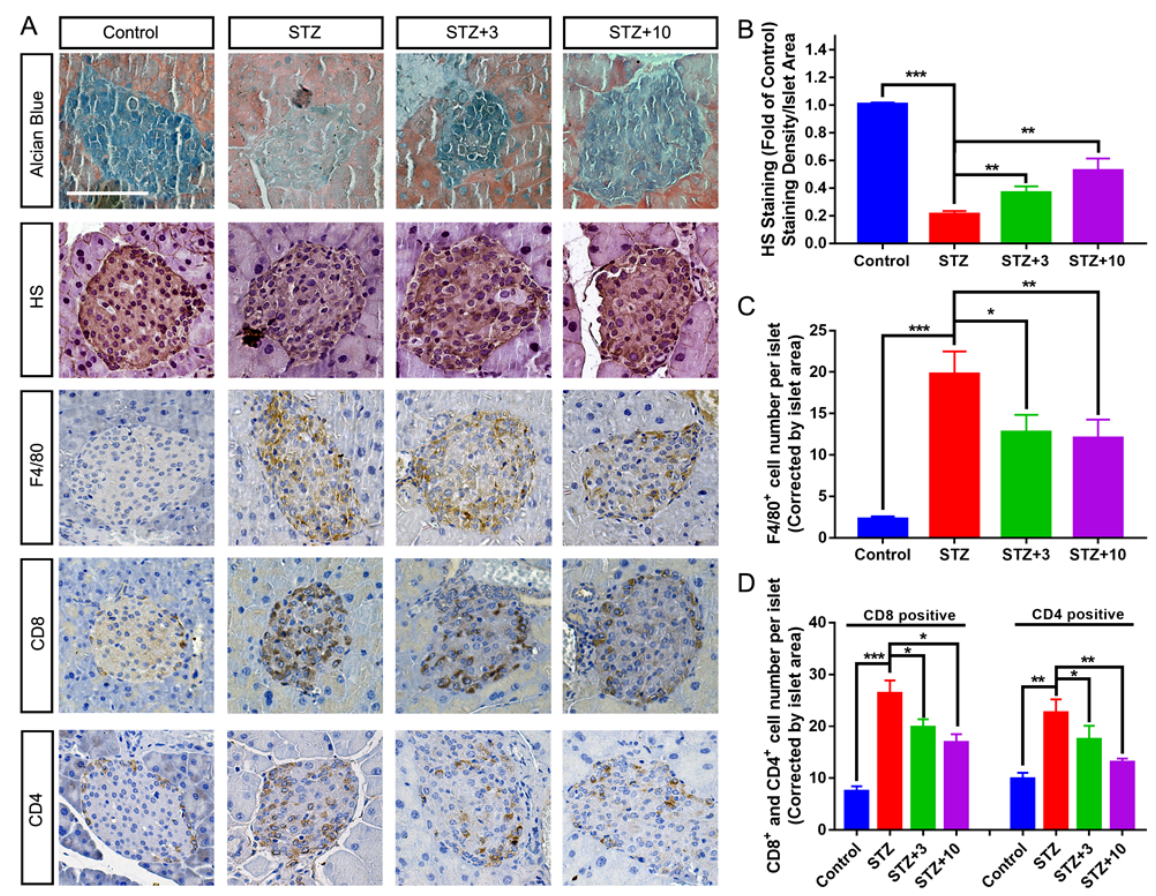

Figure 5. OGT2115 increased intra-islet HS levels and reduced the infiltration of monocytes 
in STZ mice. (A) Representative images of Alcian Blue histochemical staining and heparan sulfate (HS), F4/80, CD8, and CD4 immunohistochemical staining of the islets in each OGT2115 treatment group. Scale bar $=50 \mu \mathrm{m}$. (B) Optical density of HS immunohistochemical staining based on islet area in the different treatment groups. (C) Percentage of F4/80 and (D) CD8/CD4-positive cells in the islets of the different treatment groups. ${ }^{* *} \mathrm{p}<0.01,{ }^{* * *} \mathrm{p}<0.001, \mathrm{~ns}=$ not significant as indicated, at least 10 islets were detected in each section from different group, $\mathrm{n}=10$.
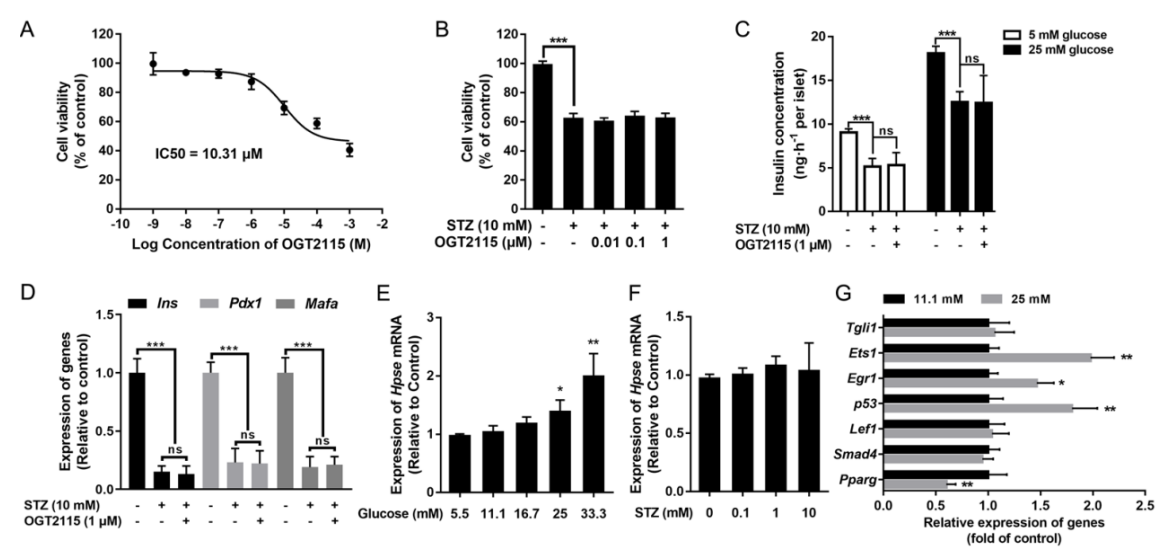

Figure 6. In vitro effect of OGT2115 on pancreatic beta cells. (A) MIN6 cells were treated with different doses of OGT2115 for $24 \mathrm{~h}$, and then cell viability was determined with the MTT assay (IC50=10.31 $\mu \mathrm{M}, \mathrm{n}=5)$. (B) Cell viability of MIN6 cells treated with STZ $(10 \mathrm{mmol} / \mathrm{L})$ in the presence of different doses of OGT2115 for $24 \mathrm{~h} .{ }^{* * *} \mathrm{p}<0.001$ as indicated, $\mathrm{n}=5$. (C) Determination of glucose stimulated insulin secretion in the different treatment of murine islets for $24 \mathrm{~h}$. ${ }^{* * *} \mathrm{p}<0.001, \mathrm{~ns}=$ not significant as indicated, $\mathrm{n}=6 ; 10$ islets per group. (D) Determination of mRNA levels of Insulin(Ins ), Pdx1, and Mafa in the different treatment of murine islets for $24 \mathrm{~h} .{ }^{* * *} \mathrm{p}<0.001$, ns $=$ not significant as indicated, $\mathrm{n}=6$. (E) Murine islets were incubated with different concentration of glucose for $24 \mathrm{~h}$, the mRNA expression level ofHeparanase (Hpse) in the murine islets was determined, $\mathrm{n}=6 .{ }^{*} \mathrm{p}<0.05,{ }^{* *} \mathrm{p}<0.01$ compared to $11.1 \mathrm{mM}$ glucose cultured group. (F) After $24 \mathrm{~h}$ treatment of different dose of STZ, the mRNA expression of Hpse in murine islets, $\mathrm{n}=6$. (G) After $24 \mathrm{~h}$ treatment in $11.1 \mathrm{mM}$ or $25 \mathrm{mM}$ glucose, the mRNA expression levels of Pparg, Smad4 , Lef1 , p53 , Egr1 ,Ets1, and Tgli1 in the murine islets. $\mathrm{n}=6 .{ }^{* * *} \mathrm{p}<0.001$, ns $=$ not significant as indicated.

A

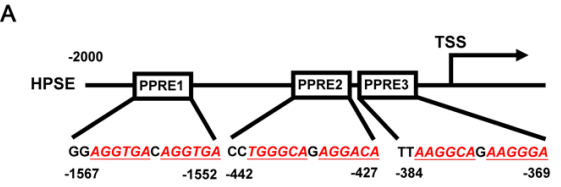

C

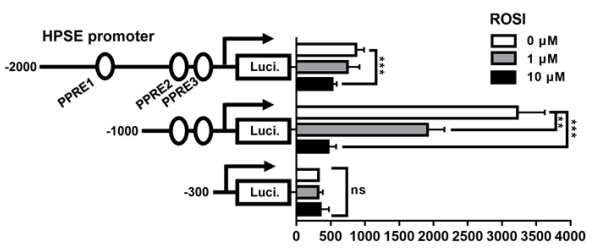

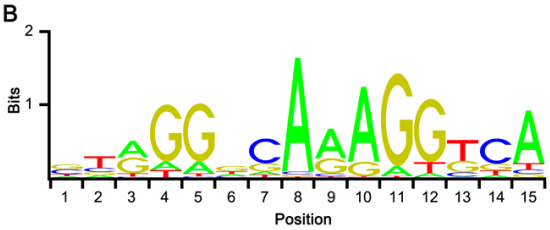

D
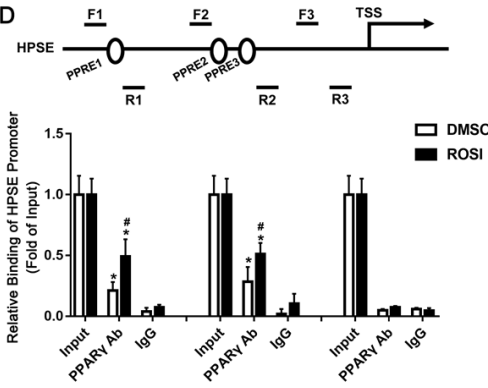


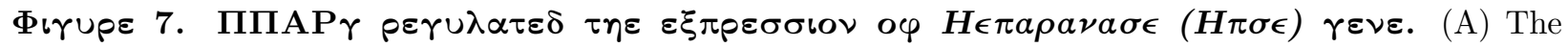
predicted sequence of PPAR $\gamma$ binding sites in the promoter region of Hpse (2000 bases forward TSS, 2000/0) according to JASPAR database. PPRE1, -1567/-1552; PPRE2, -442/-427; PPRE3, -384/-369. (B) The predicted sequence of PPRE according to JASPAR database. (C) Luciferase activity of pGL3 with different lengths of the promoter region of Hpse genes (-2000/0), pGL3 (-1,000/0), pGL3 (-300/0), and pGL3 basic reporter plasmids co-transfected with PPAR $\gamma$ in 293T, and rosiglitazone (ROSI) was used to activate PPAR $\gamma .{ }^{* *} \mathrm{p}<0.01,{ }^{* * *} \mathrm{p}<0.001, \mathrm{~ns}=$ not significant as indicated, $\mathrm{n}=6$. (D) Interaction of the PPAR $\gamma$ and the promoter region of Hpse was detected by chromatin immunoprecipitation in 293T; rosiglitazone was used to activate PPAR $\gamma .(\mathrm{n}=6) .{ }^{*} \mathrm{p}<0.05$ in PPAR $\gamma$ antibody $(\mathrm{Ab})$ treated group compared to input control, $\# \mathrm{p}<0.05$ in ROSI-stimulated group compared to DMSO-treated control.
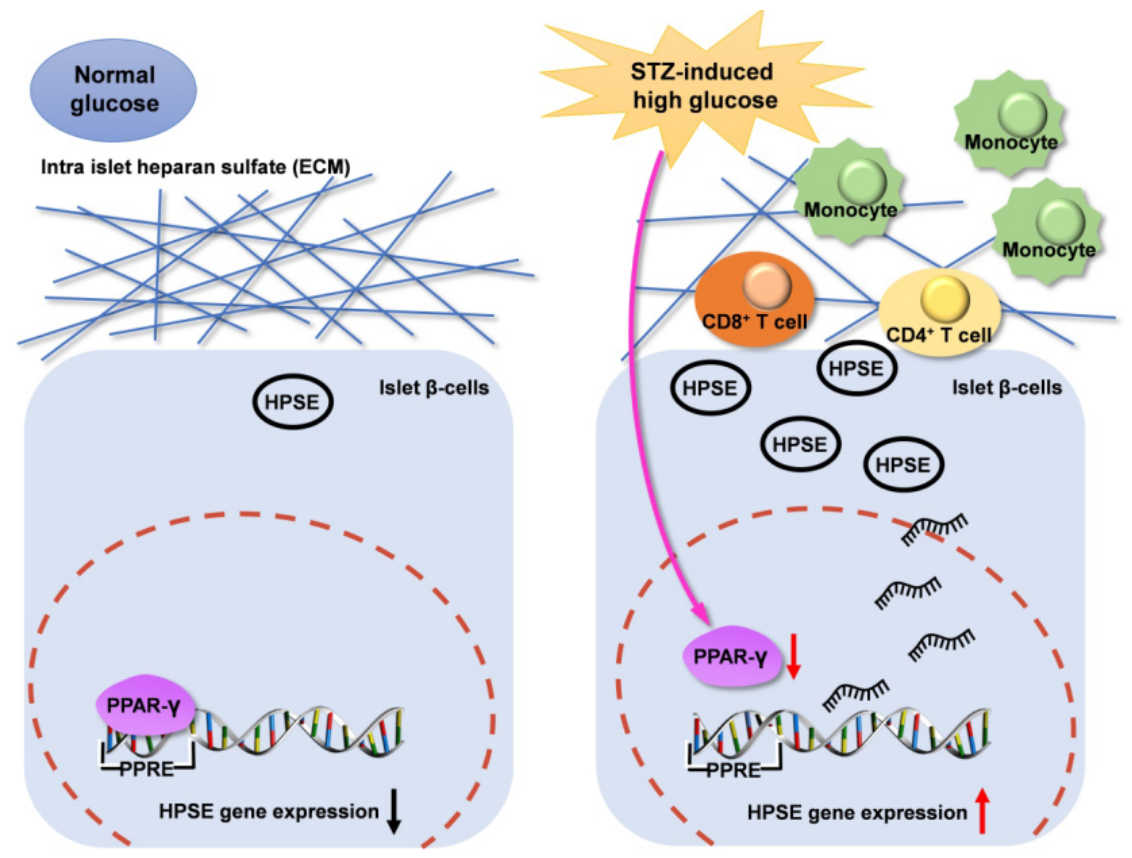

\section{Graphic Abstract Image}



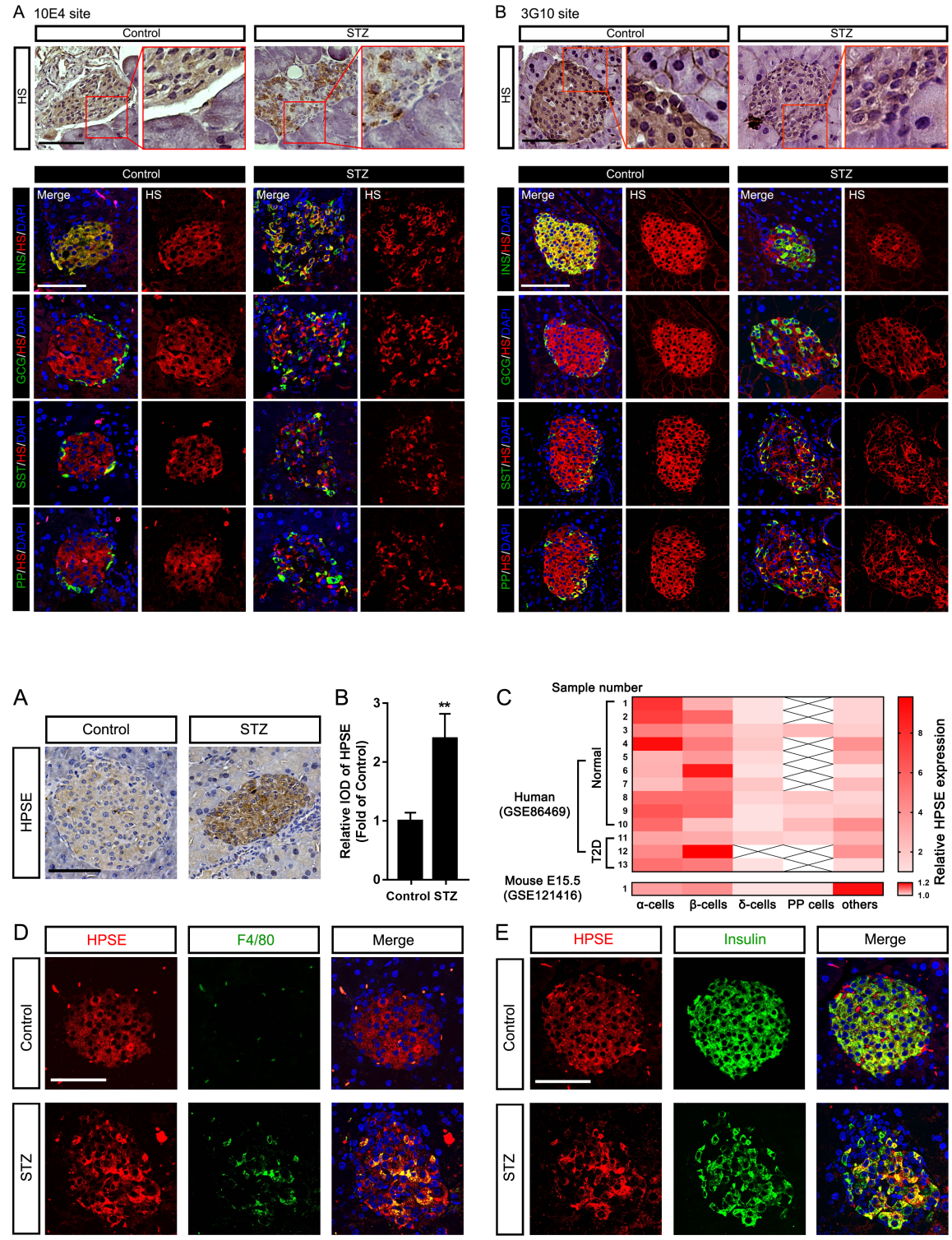

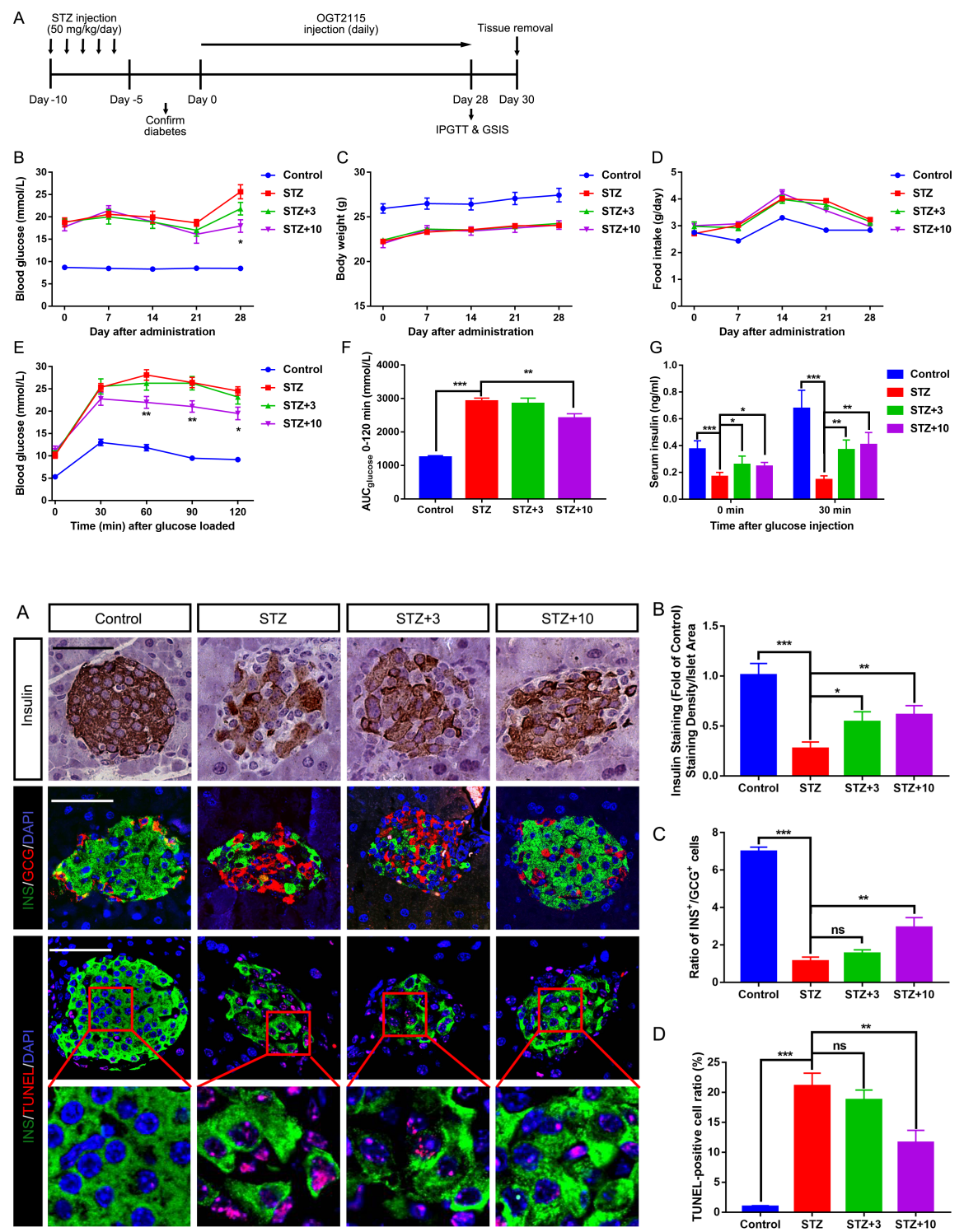

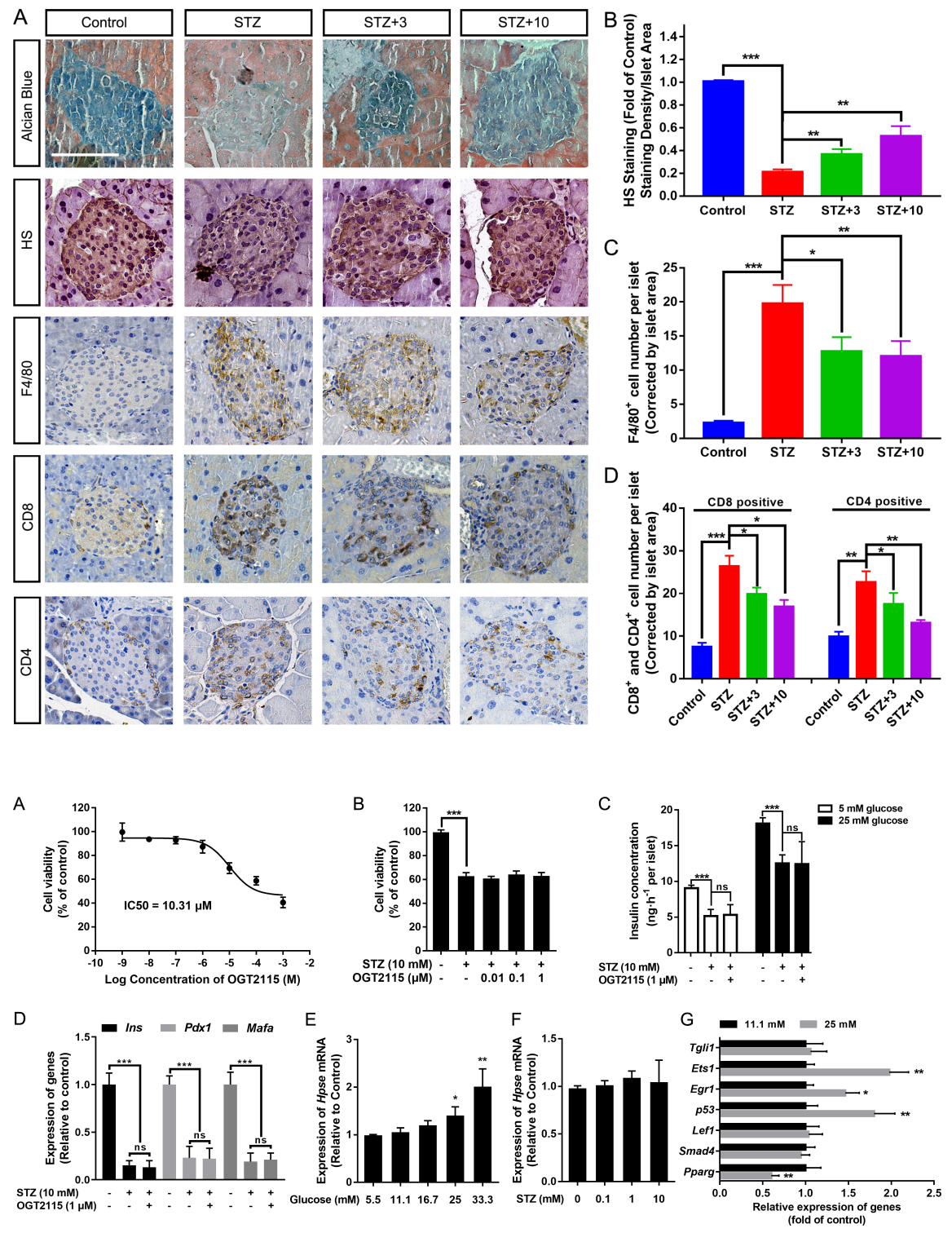
A

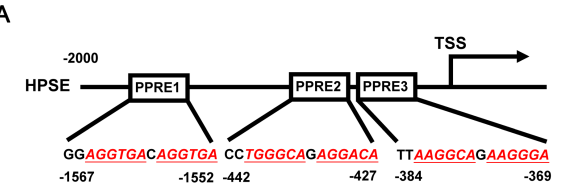

C

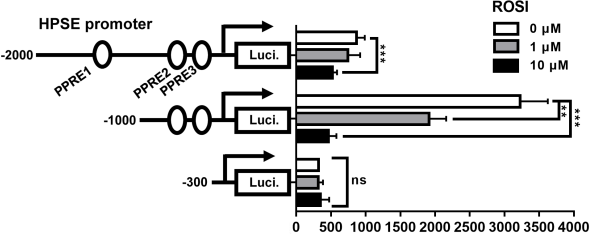

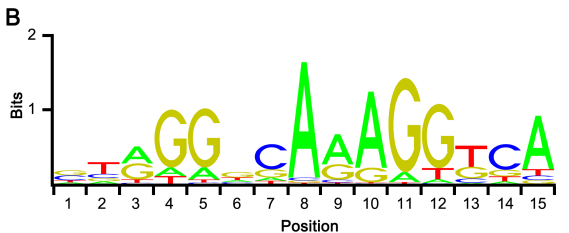

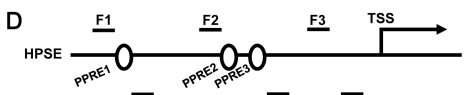

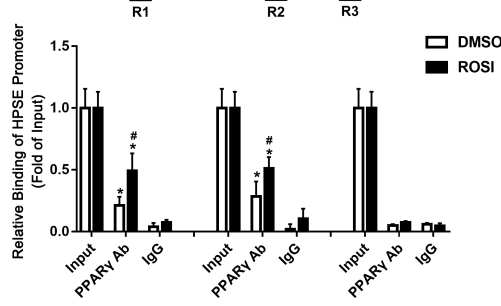

